Article

\title{
Financial Literacy Education with an Aboriginal Community: Identifying Critical Moments for Enabling Praxis
}

\author{
Levon Ellen Blue $\mathbb{D}$ \\ Indigenous Research and Engagement Unit, Queensland University of Technology, Kelvin Grove 4059, Australia; \\ levon.blue@qut.edu.au
}

Received: 7 November 2018; Accepted: 7 January 2019; Published: 10 January 2019

check for updates

\begin{abstract}
Conventional financial literacy education (FLE) practices promote individual choice and responsibility for financial circumstances. The untruth connected to conventional FLE is that achieving financial well-being is possible after acquiring financial skills and knowledge and choosing to make effective financial decisions. In this article, I share an exploration of FLE practices with an Aboriginal community that unfolded after a conventional train-the-trainer financial literacy workshop failed to gain traction. Nineteen semi-structured interviews took place with community members to understand their experiences, interest and perceived relevance of FLE. The importance of site-specific FLE was revealed as the tension between individual wealth accumulation practices promoted in conventional FLE collided with Indigenous ways of being, knowing and doing. Identified are critical moments for reflection that may enable praxis in FLE. By enabling praxis an educator moves away from conventional one-size-fits-all approaches to FLE, where participants' needs are assumed, and towards more tailored approaches.
\end{abstract}

Keywords: financial literacy education; praxis; financial literacy; indigenous

\section{Introduction}

Financial literacy is commonly understood to be about individuals acquiring skills and knowledge to make effective financial decisions through the adoption of behaviours and attitudes that then lead to financial well-being. Although the discourse may now be shifting from financial literacy to financial capability, with a focus on achieving financial well-being, the terms financial literacy and financial capability are often used interchangeably. The individualistic focus of financial literacy education (FLE) has been questioned and an alternative approach to FLE, an approach that considers how financial decisions affect both the individuals and society, has been advocated [1]. Of concern is that FLE is part of the problem, and not the solution [2], as FLE is "incurably optimistic despite the paucity of gains their initiatives have had in improving the security and freedom of most" ([3], p. 227). Biesta [4] questions the purpose of education in an age of measurement. He directs us to Bogotch et al.'s [5] concerns about "effective education" and questions what it is effective at doing and who it is effective for. This is especially important to consider since FLE initiatives often target disadvantaged and marginalised individuals for whom these educational workshops may cause participants to blame oneself for the inability to easily change financial circumstances. Thus, the need "to involve solidarity expressed through curriculum and pedagogy that values, respects and builds upon the knowledge and cultural backgrounds of students" ([6], p. 107) is likely essential for successful outcomes for marginalised students. Furthermore, with financial well-being positioned as the ultimate aim of most financial literacy initiatives [7], this elusive state of well-being may never be achieved through financial skill and knowledge acquisition and/or attitude and behaviour changes for individuals living on low incomes [8,9]. 
Therefore, I argue the need to expunge all notions of financial literacy that align the acquisition of financial skills and knowledge to financial well-being. Instead I argue for FLE as the teaching that explores "financial dilemmas," as coined by Sawatzki ([10], p. 559), that are contextually, culturally and age appropriate [10]. FLE "also involves students acquiring financial skills in a social context and the ability to develop multiple solutions through collaborative discussions instead of focusing on individual financial practice and independent work" ([11], p. 93). The research described in this paper addresses Meaney et al.'s [12] call for action so that "moral change in how mathematical education research is promoted and undertaken with Indigenous students, with a need to include greater Indigenous community representation" (p. 143). Thus, the research question guiding this paper is: how might FLE move towards praxis approaches?

\section{How This Research Came About}

FLE train-the-trainer multiple-day workshops continue to be offered to community organisations working with low-income individuals in Australia and Canada $[13,14]$. These FLE workshops and resources are usually developed and/or financially supported by financial institutions, thus causing concern about a hidden curriculum. Of particular concern with this approach to training and learning is the praxis of FLE. Educational praxis is "the moral, ethical and caring dimension of teaching" ([15], p. 1) that appears to be lacking in conventional forms of FLE practices. Kemmis [16] argues that:

[e]ducational action is a species of praxis in both these senses [referring to the Aristotelian sense of being morally committed and informed by the field of practice and the Hegel and Marxist sense as history-making action] because, on the one side, it involves the morally informed and committed action of those who practise education, and, on the other, it helps to shape social formations and conditions as well as people and their ideas, their commitments and their consciousness. (p. 10)

Understanding that the aim of training is often to learn a skill, which is different from teaching nevertheless praxis, still has an important place in both learning environments, In this paper, I examine the trend to educate some individuals living with structural risks (such as poverty and lower education levels) in society with generic FLE. This study occurred after a nationally used FLE train-the-trainer workshop failed to gain traction in an Aboriginal community. In conjunction with some Community members, the approaches to learning, the relevance of FLE, and their felt needs regarding FLE were explored.

\section{Research with the Community I Am From: Methodological Approaches and Methods}

Indigenous research methodologies guided my research approach, as did my relational accountabilities [17,18]. Wilson [17] views relational accountabilities as research that is community based that demonstrates relevance, respect, reciprocity and responsibility to the Community. Martin [19] reminds us of the interrelatedness of Aboriginal knowledges that is "insight based on hindsight for the purpose of foresight" (p. 135). This insight into financial practices allows researchers such as myself who have a foot in both worlds the ability to interpret the nexus of conventional (individual wealth accumulating) approaches to FLE and compassionate (consider the effect on financial decisions on others) approaches to FLE. A similarity shared between Indigenous methodologies and qualitative methodologies are the methods used, such as interviews. Differences between methodologies have to do with the relational accountabilities associated with Indigenous research [17]. Relational accountabilities are the connections an individual has with the participants and how that individual's connections to the community places them and establishes an underlying acceptance of shared knowledge and experiences. For me, my relationship to the Community placed an overlying accountability on me to do the right thing during this research. Martin [19], with authority, argues that: 
some connections come and go and some are constant for much of our lives. But it is when these connections are so deep and so close that a change (positive or not), has an impact that is so profound because it is too real, that's more about Connectedness. (p. 83)

This connectedness-“to place[s], times and events" ([19], p. 86) - is another difference between Indigenous research methodologies and qualitative methodologies when conducted by a researcher who is from the Community they are researching in.

As a researcher of Aboriginal (Ojibway) heritage, conducting research with some Community members involved me to "go to Country" twice during this research to " ... keep that part of [my] DNA humming within [myself] and [my] relationship" ([19], p. 7). My obligations to the relationships established, re-established and/or strengthened during this process guided my approach and ultimately determined the direction I followed. The main research method used during my time in the Community was interviews, both individual and group (19 in total), as determined and preferred by the Community members involved. Other methods used included participating in Community events, meeting with the Chief and the Council, observations, and field notes. I continue to gain insight from my experiences on Country with Community members who hold much knowledge and foresight.

This study is case oriented, contextually developed and non-comparative in nature, thus seeking to understand this particular case, not how it is similar or different from other communities [20]. The fieldwork component of the study took place during two visits to the Community: one in October 2013 and the other in June 2014. The nature of the fieldwork was non-interventionist, with an emphasis on interviews and invited opportunities to speak with members of the Community. This study was a "researcher-subject interaction" ([20], p. 47), meaning that my subjectivity as a researcher and Community member was acknowledged and used to make responsible and respectful decisions.

Indigenous methodologies share both similarities and differences with qualitative research approaches [21], with the similarities being some of the methods and the differences being the relational accountabilities $[17,22]$. It was my family connections and established relationships to this Community that placed me in a position to conduct this research. However, conducting research with some fellow Community members also came with the responsibility to "do the right thing" by both family members and my Community as an overlying accountability. Relational accountabilities are also about how a researcher only gains access to "officially" interview other Community members because of the relationship established by a member of their family. The trusted family member provides assurance and a guarantee that is it safe to speak with this researcher. When this occurs, the added responsibility placed on the researcher to do the right thing remains with the researcher long after the interview is finished, as not everything said should be shared publicly. This is the extra responsibility a researcher faces when they imagine what the Community might be saying or thinking about what they decide to share with the world [23].

\subsection{Study Design and Research Context}

This research is a case study that explored the FLE practices in an Aboriginal community in Canada. The community is a financially excluded community located on a First Nations reservation in the province of Ontario. This Canadian First Nations community is located on a reservation that is on an island. Approximately 620 residents or 250 households live on the reservation year-round, and approximately 1000 members live off the reserve [24]. The study began approximately one year after a train-the-trainer financial literacy workshop (developed by an established outside organisation) was offered in the Community. The established charitable organisation, which was funded by a large financial institution, was invited to the Community to deliver their multiple-day workshop to help improve the financial literacy of some Community members (mostly staff employed in the Community). Their national financial literacy package focused first on the participants acquiring financial literacy themselves; and second, for them to pass this newly acquired knowledge on to the individuals living in the community. Despite a needs assessment being conducted prior to the workshops, the site may not have been fully understood by the fly-in and fly-out facilitators. 
I conducted interviews with individuals and with groups of Community members who had either attended the previous financial literacy workshops and/or had an interest in financial literacy. I did not define the term financial literacy to the participants as there appeared to be an understanding by the participants about what financial literacy meant. By interest in financial literacy, I mean, individuals who wanted to be interviewed and were recommended to me to speak with. FLE was also not defined but taken to be understood as education that focused on personal finances such as the financial literacy train-the-trainer workshop and other sessions run by a local bank.

Nineteen participants were interviewed and their audio-recorded interviews were transcribed. During these interviews, I explored their perspectives of the workshop and its effectiveness in developing new trainers, and the relevance, interest and perception of financial literacy in Community.

The following five interview questions were asked during the interviews:

1. Who taught you about money? Do you discuss money with others? If so, who?

2. Have you attended a FLE workshop or course? If so, has FLE teachings/advice impacted your financial practices? If so, in what way? If not, do you think it could?

3. Is FLE relevant to you and the Community? If so, which FLE topics? If not, why not?

4. Is FLE required to strengthen the financial futures of the next generation in this Community?

5. How would effective and relevant FLE operate in the Community?

\subsection{The Participants}

Purposeful sampling and then snowball sampling were used during this study $[25,26]$. Following these two sampling processes meant that the Community was deliberately selected to provide an in-depth understanding of the practice of FLE [26]. The participants who were selected for interviews began with the Community members who had been involved in the formal FLE initiatives in the Community. The remaining interviews resulted from the snowball sampling method, where interviewees recommended someone else who could be contacted for an interview. All interviews were semi-structured and focused on the Community members' experience, interest and relevance of FLE.

Four themes framed these interviews. The themes included Community members': experience with FLE; interest in FLE; perception of what FLE can/cannot achieve and its relevance; and, the vision for financial futures of Community members.

Of the 19 Community members interviewed, there were 12 females and seven males, with 10 interviews conducted individually and four in groups. The average interview length was 45 min. Three distinct participant groups were included in this study:

1. Group 1: Official Community members (living on or off reserve and listed as members of the Community by the Band Office);

2. Group 2: Unofficial Community members (living on or off reserve and not listed as members of the Community by the Band Office due to being excluded by purposeful and discriminatory government policy, but sharing family connections to Community members);

3. Group 3: Non-Community members holding key positions in the Community (recommended to me by the Chief and Council to interview).

\subsection{Data Analysis}

NVivo software was used to analyse the data. Initially, this involved transcribing the audio recordings of interviews and observations. Care was taken to immediately transcribe the recordings, and when this was not possible, thoughts about each interview were written down immediately after the event. The data were continually analysed as part of the research process to align theory with the findings. Observational notes and/or memos were also typed and imported into NVivo. All data uploaded into NVivo were then coded to identify themes. Once themes were identified from the data 
they were compared to those reported in the literature about financial literacy, and notes were recorded about what the themes might mean in relation to the theory of practice architectures.

A line-by-line analysis was undertaken and passages of text were coded to one or many nodes. This coding process of "slicing" the data meant that multiple codes could be applied to a single passage of text [27]. The next step involved interpretation, where "slicing" the data "opens up analytical possibilities through the recombination of coded passages" (p. 75). Through this process, identifying themes and creating nodes in NVivo provided increased flexibility when searching for questions to ask of the data [27]. In total there were 50 themes that were shown as nodes in NVIVO.

Themes about experience with FLE, interest in FLE and relevance of FLE were first identified, with other themes uncovered during the coding process. Emergent themes were generated as patterns or "occurrences" that were identified during the process and began to act as a link to new or emergent patterns in the data [28]. Yin [29] also discussed a two-phased strategy for case study analysis; the first phase involves reviewing all the data in its various forms and analysing it deductively and then inductively in the second phase. Thematic coding was used during the deductive phase as data passages were reviewed and assigned a code. In the second phase, the inductive analysis may result in new themes emerging from the data, which may have been overlooked if only the first phase was used. During this phase, clean copies of the data were analysed to enable new themes to emerge that were compared and contrasted with the themes uncovered during the deductive phase.

\section{Theoretical and Contextual Framing}

Practice theory [30] was used as a theoretical lens to understand the Community's FLE practices (the sayings, doing and relating in a financial context). Practices include the sayings, doing and relating that are particular to a site and are amid arrangements in intersubjective spaces (semantic, physical and social) where people encounter each other [30]. By exploring how FLE was practised in an Aboriginal community located on a reservation, it was important to consider that: (1) current FLE practices may be attempting to colonise individuals into a certain way of being and behaving that may not always be in the participants' best interest (as shown with entrepreneurship education initiatives in Aboriginal communities) [31]. Instead, the interests of governments and political agendas designed to reform an individual's financial decision-making may be driving these FLE practices [32,33]. The sustainability of current FLE practice arrangements and unrealistic promises of how financial literacy can improve the conditions of possibility within this Community must be realised via a thorough understanding of the site, including the often harsh realities of life on an Aboriginal reservation. By taking time to gain an understanding of the site, more realistic expectations and outcomes for FLE within such sites can be identified. This richer, contextualised knowledge may help educational initiatives developed within the site, as shown by Sawatzki [34,35]. Hunter et al. [36] argue that student engagement is greater when links are made "to the student's cultural and social experiences" (p. 225).

\section{Uncovering Another Way-Enabling Praxis in FLE}

Without praxis, we run the risk of removing the possibility of positive identity building. "We are also led to believe that our identity can be self-determining and yet it is only in relation to others that we come to understand more of ourselves" [17] (p. 71). Thus, the importance of fostering positive self-identity in classrooms begins with a praxis approach to education. McInerney [37] asserts that "there is little doubt that teachers are significant persons in contributing to the development of positive self identity for Indigenous students" (p. 21). Students from a low SES background were shown to have low beliefs about their abilities in mathematics classrooms [38] and likely their financial capabilities. Edwards-Groves et al. [39] argue that "the education profession must thus be conceptualised as a praxis-oriented profession - that is, as a profession oriented towards the praxis of those who participate in it (and are affected by it), particularly the praxis of teachers and students" (p. 52).

The utmost importance of positive identity building in education means avoiding pedagogical practices such as deficit perspectives about people, places and all living things from being initiated 
and replicated. I raise this point, as educators operating from a praxis perspective may indeed believe that conventional FLE practices are "helping" to "empower" individuals to be "effective" financial decision-makers. However, because conventional FLE can promote a financial ideology that values financial net worth, a change in practice is required, or a deficit approach to FLE without a praxis understanding of the site may prevail.

Enabling praxis also involves abandoning a one-size-fits-all approach to education because each site has specific circumstances and conditions [30]. Site-based education development was an important aspect of this research project, particularly since the generalised "best practice" notions of FLE are based on a deficit perspective.

In the next section critical moments for praxis in FLE are identified. A critical moment, in this context is related to how Kemmis, McTaggart and Nixon [40] view critical theory and practice as a way to lead educators "to richer understandings of social and educational practice and how to change $i t^{\prime \prime}$ (p. 2). The four critical moments outlined below were determined after reviewing the themes and reflecting on the overall findings from this research.

\subsection{Critical Moment 1: Identifying Contextual (or Site-Specific) Concerns Relating to Financial Matters}

Before I arrived back in the Community, a financial literacy train-the-trainer workshop had already taken place. An outside organisation that provides financial literacy train-the-trainer workshops nationally was invited to deliver this workshop in the Community. Some Community members did meet with this charitable organisation prior to the workshop taking place. However, none of the participants was willing to become a financial literacy trainer afterwards. I was informed that the participants were more interested in the curriculum content and less interested in becoming trainers. However, the training organisation wanted trainers and measured their success by the number of new trainers trained. Thus, what emerged was a need to change practice by reflecting on what was of relevance to the Community and identifying how FLE could operate in the Community. The planning of this event is what reconnected me to my Community in a "formal" way-a connection to Community that is never lost. "For Aboriginal peoples, Places are valued because they are more than 'home' they are Places of origin of Creators and also Ancestors. These Places are about one's DNA, they are essential to Identity and Connectedness" [19] (p. 98). Despite my living in Australia, a Community member suggested that I be contacted because of my knowledge of financial literacy. When I was formally invited back to the Community to speak at a Community Summit, it was approximately one year after the financial literacy train-the-trainer workshop had taken place. I commenced the current research by reconnecting with some Community members and asking about the relevance of FLE rather than making assumptions about their FLE needs. Community member Zhaawan stated that FLE was relevant because:

You know everyone wants to learn about money and everyone wants to-I guess, it's like everything revolves around it right? It brings out either positive behaviours or negative behaviours that everyone sees, especially in a small community.

The interest in FLE is stated in Zhaawan quote above. However, enabling and constraining FLE practices influences and has effects on the sayings, doings and relatings of an individual and in a social context [30]. With regard to the cultural-discursive arrangements, it was the language used between people (instructor to participant, participant to instructor, and participant to participant) in a financial context that enabled and constrained certain practices. The material-economic arrangements, such as the activities used in the workshop and the resources (FLE booklets), also enabled and constrained practice as participants began to compare the promoted financial practices with their own financial practices. Thus, a tension with Indigenous ways of knowing, being and doing [41] emerged when examining the individualistic wealth-accumulating FLE practices promoted in conventional workshops $[8,42]$. These tensions (often unspoken but felt), which may also be prevalent in other 
cultures, also affect relationships (social political arrangements) and practices such as establishing savings when a high percentage of the population is on social assistance:

I don't see any new income or any new jobs coming about or anything that will grow the economy happening here at all. (Mgizwaash, Male)

Despite a lack of employment opportunities in the Community there was a strong focus on the support from leaders in the Community to ensure there were better opportunities for the future for the young people. Offering FLE to the young people, especially those leaving the Community for post-secondary education, was identified as required. However, some of the activities involved in the FLE resources did target specific financial skills and/or knowledge. By way of example, the "exploring our relationship with money" (included in module 1 of the train-the-trainer workshop) asked participants to "find someone who rents a home, plays the lottery and doesn't want to be rich" [43]. The connection between the activity described above and the needs of the participants seeking FLE was not clear. It is also difficult to determine what skill and/or knowledge was being demonstrated in this example. Enabling and constraining relationships include how Community members relate to others in a financial context both on and off the island. An individual may develop a financial identity as either a financially literate or financially illiterate individual [9]. This identity may have an effect on the way individuals relate in a financial context. As relationships have both an individual and social aspect, the social side of relating is more about the shared understanding of life on the reservation or as a Community member living off-reservation. As differences in meanings and practices emerge, non-Community members' understanding of Indigenous ways of knowing, being and doing [41] in a financial context is challenged. An example: Community member Bne stated that:

[Indigenous people] are funded by and can only be funded by grants and that's what we have to do each year; and even the programs at the [Indigenous] admin office, they have to submit their grant application every single year and this is what we are getting from the government. Now, people on the outside don't understand this, and they think we have all this potential to have great businesses and stuff like that, but we have no collateral. Because we can't do that [easily access bank loans to establish businesses on the reservation] and banking institutions rely on collateral and we don't have any of that, so no one would ever fund us if we wanted to go into a [type of] business. We won't be able to do it because, financially, no institution would finance us. So it's a matter of 'okay, where do we go now?'

Homes on many reserves in Canada are held in trust by the council for the government. The financial reality of having your main asset (your home) not considered as collateral by financial institutions and not being able to pass on wealth to family through the inheritance of property (with collateral value) continues to have an impact on the financial circumstances of members of this Community.

\subsection{Critical Moment 2: Appropriate Pedagogical Practices Required to Suit the Community}

When discussing with Community members what their interests were in FLE, I was reminded of how the individual choice discourse is so prevalent in conventional FLE. As the excerpt below highlights, FLE was sought to help Community members save their money and stretch their funds. However, FLE may only provide financial awareness; it does not increase the ability to save, as only an increase in income may have an impact on an individual's ability to save:

Yes it is and we have had it. We have had a few sessions where we had the banks and different financial advisors because ... we wanted people to know the banking information and how to do this and how to save and how to make that money last. (Waahzii, Female)

As mentioned above, offering FLE and/or financial advice workshops in the Community is not new. However, what was reported was a need for a delivery mode that Community members would 
be comfortable with. It was reported that no one was comfortable teaching FLE to others using the train-the-trainer model:

No, the majority that were there thought it was a pretty good course and gave them some awareness into financial literacy and what to look at and what to expect around budgeting and all that but they all agreed that, or the majority agreed that they wouldn't be willing to go out and teach people. (Shiishiib, Male)

A lack of confidence in presenting financial content and, more specifically, presenting in general was identified as the main problem with the train-the-trainer delivering mode. Shiishiib went on to comment:

They would be uncomfortable presenting and I think presenting is another piece in itself that is not specific to financial literacy but with anything. You know presenting anything, they are uncomfortable with that.

The importance of a delivery mode that Community members were comfortable using was discussed:

... designing a program or a model that we can use in our community that people would be comfortable using and delivery it in our own style whether it is one on one or group sessions or even if it comes down to people deciding that we would like an independent person not part of any staff to be delivering this type of information as like an advisor that comes in once in a while, so maybe more people are comfortable with that because they don't have to devolve their financial information or their habits. (Shiishiib, Male)

It was also mentioned that the prescriptive nature of the one-size-fits-all FLE resource had the potential to be off-putting to Community members:

I think more of a guidance thing. I don't like to be told to, if I was to be in their shoes I wouldn't like to be told I have to do this and I most likely won't pay attention. But more guidance through steps to take the counselling part, like a map, instead of doing it for them, showing them how to, not coddling. (Pichiin, Female)

Using a pedagogical approach that Community members would participate in starts with an understanding of the unique conditions of the site, including the prevailing practice architectures that enable and constrain practices within the Community [8]. Thus, a new practice introduced into the Community that was mediated through outsiders without an understanding of the prevailing practice architectures was unlikely to gain traction. Instead, with some Community members a need for a financial practice was identified, and through discussions with the counsellors working for a government department in the Community it was identified where within their own processes this training could be embedded and delivered by the counsellors. This is a small example of how relevant FLE practices can be sustainable in the Community when they are consciously considered and embedded into existing practices.

\subsection{Critical Moment 3: Do No Harm and Inflict No Shame}

In any teaching environment, it is essential to do no harm. Enabling praxis in FLE involves an educator considering and/or anticipating how individuals may feel before, during and after their workshop. This understanding is obtained through knowledge of the site and relationships with Community members. A thorough understanding of the site ensures that the participants are not viewed as the deficit.

Enabling praxis means conceptualising how shame could be inflicted on individuals (e.g., who are living in poverty or on low incomes) by the content you are teaching and/or by the methods, examples, and activities used. FLE is not always taught from a deficit view but when it is, focusing on the 
individual and a belief that if only the individual tried harder they would have better financial circumstance can result in shame being inflicted on the participants. A critical and compassionate approach to FLE would focus instead on the systemic barriers and obstacles that individuals face living under a capitalist economic system [1,44,45]:

You don't want to make them [individuals receiving social assistance] feel like how they already feel [shame]. (Zhaawan, Female)

Attending group-run finance workshops in a small Community may have also been a barrier to some Community members who may have wanted to attend but were too embarrassed for others to see them at the workshop. The taboo and private matter of personal finances means that just attending a group workshop could bring unwanted attention to an individual and their financial circumstances.

I think that is where their reluctance might be, they don't want to devolve it to somebody even though in those, like in this office, we know. (Kyaashk, Male)

Poor attendance at workshops may have been attributed to the frequency of training offered in the Community by outside organisations that were reported to not understand how the Community operates. The other issue with train-the-trainer model is that after receiving the training participants are now deemed quasi "financial literacy experts." The financial experts were now also expected to offer training to others in the same format-that is, group workshops-and some Community members did not think that would appeal to others:

So I think that part of the reluctance in moving that [FLE] forward ... [is] how you present [it] and what are some of the options we should look at for delivering this type of information and doing it freely at the people's own will when they decide they are ready to do this and the option is there for them. And I think if we look at the approach from that perspective and the way most people might be comfortable with getting the information and the [advice]. (Shiishiib, Male)

Another concern about personal finances was coming into money (e.g., treaty settlements) when many Community members are not used to having money. Not having money and then coming into money manifested as a need to get rid of the uncomfortable feeling about money:

I think it is the case of most communities that aren't used to having money ... I think there still is a lot of training with regards to money that needs to be done but I find in the Community when people have money, they spend the money, they don't think ahead, they don't think about tomorrow, they need their food and they need stuff their now. In a way I am guilty of that in some ways and so are my children and it just probably wouldn't say a necessity but you know, you get your money and you go over [to the mainland] and you buy your bulk food and your bulk groceries and stuff like that so that for the month you have that. Myself, money doesn't really mean a whole lot if I can pay my bills and buy my grocery and food that's all. I am happy that way. (Waabzii, Female)

Helping others in need through Community fundraising events was an important way of contributing to Community members.

\subsection{Critical Moment 4: Concern for Others-Financial Practices in the Community}

A Community fundraising event called a "loonie auction" occurred while this research was being conducted. A "loonie" refers to a Canadian loon (a bird) that appears on the $\$ 1.00 \mathrm{coin}$. This fundraising activity in the Community was held for a family in need of financial support. A Community member referred to this type of event as a way to release guilt associated with having money, especially when others are in need. An individual's feelings, thoughts and talking about guilt or shame (the sayings) may affect what s/he does with money (e.g., gives it away-the doings) and how they relate with 
others (the relating) at Community fundraising events. Thus, the connection of financial practices and the sayings, doings, and relating in a financial context become apparent [42]. Some of the reluctance for engaging with FLE workshops offered by outside organisations may be explained by a lack of understanding of communities' financial practices and community members' concern for others. The "loonie auction" is an example of a financial practice that demonstrates concern for others.

Community members also discussed the need to feel good about financial decision-making by helping others and by being able to afford something that they could not previously afford.

So I think looking at those creative solutions [to raising money] because people will give because you do feel good. (Shiishiib, Male)

A feeling of happiness was described when a Community member recalled a family member being in a position to purchase something that they could not previously afford:

Definitely, you can still see it in many people in the Community and even within my own family whether it is a winning from a scratch ticket, a bonus or something that happened and the immediate response was and still, let's spend it, let's buy something with it. And whatever we bought brought all this great happiness because we could buy it. Rather than thinking this is great, we got this [money], now let's put it in the bank or pay down this debt or invest. There was none of that and there still is a sense of happiness that is associated with spending. I guess you could compare it with people that celebrate with food, the community. (Diindiisii, Female)

In summary, based on the critical moments identified above, it is recommended that FLE is site specific and pedagogically appropriate (e.g., participants are able to attend without becoming trainers); does no harm and inflicts no shame (e.g., acknowledges that improving financial circumstances does not just come down to acquiring skills and knowledge); is designed and delivered using pedagogical practices that Community members are comfortable with; and, reflects a concerns for self and others by valuing Indigenous ways of doing, being and knowing. Thus, understanding the financial practices in a community and the conditions of the site enables a more collective approach to financial decision-making.

\section{Conclusions}

This research explored the FLE practices in a Canadian Aboriginal community (that I am a member of) as a case study. I returned twice to conduct this research in a collaborative manner that included participating in the Community events and reconnecting and strengthening relationships. The impetus for this study came from some Community members seeking FLE. Nineteen semi-structured interviews were conducted with Community members to understand the relevance and importance of FLE in this context. Relationship-building guided my approach to research in my Community, meaning that it was essential that I left the Community with a stronger relationship than I had going in. Practice theory was used in conjunction with Indigenous ways of doing, being and knowing to understand the sayings, doings and relating in a FLE practices context. This research with Community instead of for Community meant that the importance and relevance of FLE was sought from Community members to understand the FLE needs of the Community. It is important to note that, although some of the curriculum content was valuable, the activities and train-the-trainer approach required some modification. This research and the findings challenge the narrow, conventional and one-size-fits-all approach to FLE that lacks a broader contextual understanding of the people and place. Identified are four critical moments for reflection and action as a way towards praxis in FLE:

1. identifying contextual (or site specific) concerns relating to financial matters;

2. appropriate pedagogical practice required to suit the Community;

3. do no harm and inflict no shame; and, 
4. concern for others-financial practices in the Community

Through a richer understanding of the Community, including FLE needs, praxis is enabled.

Future research in this Community that the author is involved with includes working with youth to develop site-specific financial resources. The financial resources are being developed with Community for Community and were requested by some Community members interviewed during the research outlined in the paper. The current research project has just commenced but is based on site-specific needs relating to finance (reading and understanding financial statements, completing the budgeting section of grant applications available to Community members and providing financial awareness for Community members leaving the Community to attend post-secondary education), takes place online in a comfortable group environment, does not cause harm or inflict shame, and acknowledges concerns for others in financial practices.

Funding: This research was funded by the Fellowship Fund Inc. who awarded the author the inaugural Molly Budtz-Olson 3 year PhD fellowship.

Conflicts of Interest: The author declares no conflict of interest.

\section{References}

1. Lucey, T.A.; Agnello, M.F.; Laney, J.D. A Critically Compassionate Approach to Financial Literacy; Sense Publishers: Rotterdam, The Netherlands, 2015.

2. Willis, L.E. Against financial-literacy education. Iowa Law Rev. 2008, 94, 197.

3. Arthur, C. The Ethics of Entrepreneurship and Financial Literacy Education: A Security and Freedom for the Other. Ph.D. Dissertation, York University, York, UK, 2016. Available online: http:/ /yorkspace.library.yorku. $\mathrm{ca} /$ xmlui/handle/10315/32265 (accessed on 13 November 2017).

4. Biesta, G. Good education in an age of measurement: On the need to reconnect with the question of purpose in education. Educ. Assess. Eval. Acc. 2009, 21, 33-46. [CrossRef]

5. Bogotch, I.; Miron, L.; Biesta, G. “Effective for what; effective for whom?” Two questions SESI should not ignore. In International Handbook of School Effectiveness and School Improvement; Townsend, T., Ed.; Springer: Dordrecht, The Netherlands, 2007; pp. 93-110.

6. Mills, M.; McGregor, G.; Baroutsis, A.; Te Riele, K.; Hayes, D. Alternative education and social justice: Considering issues of affective and contributive justice. Crit. Stud. Educ. 2016, 57, 100-115. [CrossRef]

7. Organisation for Economic and Cooperative Development (OECD). Improving Financial Literacy: Analysis of Issues and Policies; OECD Publishing: Paris, France, 2005.

8. Blue, L.E. Exploring the Financial Literacy Education Practices in a Canadian Aboriginal Community: A Case Study. PhD Dissertation, Griffith University, Queensland, Australia, 2016.

9. Blue, L.E.; Grootenboer, P.J.; Brimble, M.A. The importance of praxis in financial literacy education: An Indigenous perspective. In Proceedings of the 38th Annual Conference of the Mathematics Education Research Group of Australasia, Sunshine Coast, Australia, June 2015; pp. 91-105.

10. Sawatzki, C. Connecting social and mathematical thinking: The use of "real life" contexts. In Proceedings of the 37th Annual Conference of the Mathematics Education Research Group of Australasia, Sydney, Australia, June 2014; pp. 557-564.

11. Blue, L.E. Financial literacy education practices with Aboriginal people: the importance of culture and context. Financ. Plan. Res. J. 2016, 2, 91-105.

12. Meaney, T.; Edmonds-Wathen, C.; McMurchy-Pilkington, C.; Trinick, T. Distribution, recognition and representation: Mathematics education and Indigenous students. In Research in Mathematics Education in Australasia 2012-2015; Makar, K., Dole, S., Visnovska, J., Goos, M., Bennison, A., Fry, K., Eds.; Springer: Singapore, 2016; pp. 143-164.

13. Prosper Canada. Partners in Financial Empowerment. 2015. Available online: http://prospercanada.org/ (accessed on 21 November 2015).

14. MoneyMinded. Financial Skills for the Future. 5 June 2013. Available online: http:/ / www.moneyminded. com.au/about/default.asp (accessed on 13 November 2013).

15. Grootenboer, P. Praxis and mathematics education. Pedagog. Cult. Soc. 2013, 21, 321-342. [CrossRef]

16. Kemmis, S. Research for praxis: Knowing doing. Pedagog. Cult. Soc. 2010, 18, 9-27. [CrossRef] 
17. Wilson, S. Research is Ceremony: Indigenous Research Methods; Fernwood: Manitoba, MB, Canada, 2008.

18. Wilson, S. What is an Indigenous Research Methodology? Can. J. Nativ. Educ. 2001, 25, 175-180.

19. Martin, K.L. Voices and Vision: Aboriginal Early Childhood Education in Australia; Pademelon Press: Mt Victoria, Australia, 2016.

20. Stake, R.E. The Art of Case Study Research; Sage: Thousand Oaks, CA, USA, 1995.

21. Kovach, M. Indigenous Methodologies. Characteristics, Conversations, and Context; University of Toronto Press: Toronto, ON, Canada, 2009.

22. Martin, K.L. The more things change, the more they stay the same: Creativity as the next colonial turn. In A Companion to Research in Education; Reid, A.D., Hart, P.E., Peters, M.A., Eds.; Springer: Dordrecht, The Netherlands, 2014; pp. 293-296.

23. Smith, L.T. Qualitative inquiry_Past, present, and future: A critical reader. In Choosing the Margins: The Role of Research in Indigenous Struggles for Social Justice; Denzin, N.K., Giardina, M.D., Eds.; Left Coast Press: Walnut Creek, CA, USA, 2015.

24. Statistics Canada. Aboriginal People of Canada. 18 October 2012. Available online: http:/ /www12.statcan. ca/english/census01/products/analytic/compansion/abalytic/companion/abor/canada.cfm (accessed on 17 November 2012).

25. Light, R.J.; Singer, J.; Willett, J. By Design: Conducting Research on Higher Education; Harvard University Press: Cambridge, MA, USA, 1990.

26. Maxwell, J.A. Qualitative Research Design: An Interactive Approach, 3rd ed.; Sage: Thousand Oaks, CA, USA, 2013.

27. Bazeley, P.; Jackson, K. Qualitative Data Analysis with NVIVO; Sage: Thousand Oaks, CA, USA, 2013.

28. Boyatzis, R.E. Transforming Qualitative Information: Thematic Analysis and Code Development; Sage: London, UK, 1998.

29. Yin, R.K. Discovering the future of the case study method in evaluation. Eval. Pract. 1994, 15, $283-290$. [CrossRef]

30. Kemmis, S.; Wilkinson, J.; Edwards-Groves, C.; Hardy, I.; Bristol, L.; Grootenboer, P. Changing Practices, Changing Education; Springer: Singapore, 2014.

31. Pinto, L.E.; Blue, L.E. Pushing the entrepreneurial prodigy: Canadian Aboriginal Entrepreneurship Education Initiatives. Crit. Stud. Educ. 2015, 57, 358-375. [CrossRef]

32. Pinto, L.E. When politics trump evidence: Financial literacy education narratives following the global financial crisis. J. Educ. Policy 2013, 28, 95-120. [CrossRef]

33. Pinto, L.E. One size does not fit all: Conceptual concerns and moral imperatives surrounding gender-inclusive financial literacy education. CSEE 2012, 11, 177-188. [CrossRef]

34. Sawatzki., C. What Financial Dilemmas Reveal About Students' Social and Mathematical Understandings. In Proceedings of the 36th Annual Conference of the Mathematics Education Research Group of Australasia, Adelaide, Australia, June 2015; pp. 602-609.

35. Sawatzki, C. Context Counts: The Potential of Realistic Problems to Expose and Extend Social and Mathematical Understandings. In Proceedings of the 38th Annual Conference of the Mathematics Education Research Group of Australasia, Sunshine Coast, Australia, June 2015; pp. 555-562.

36. Hunter, R.; Hunter, J.; Jorgensen, R.; Choy, B.H. Innovative and powerful pedagogical practices in mathematics education. In Research in Mathematics Education in Australasia 2012-2015; Makar, K., Dole, S., Visnovska, J., Goos, M., Bennison, A., Fry, K., Eds.; Springer: Singapore, 2016; pp. 213-234.

37. McInerney, P. Counting and accounting for social justice in the devolved school: How do Indigenous students fare? Melbourne Stud. Educ. 2005, 46, 13-32. [CrossRef]

38. Grootenboer, P.; Marshman, M. Mathematics, Affect and Learning: Middle School Students' Beliefs and Attitudes about Mathematics Education; Springer: Singapore, 2016.

39. Edwards-Groves, C.; Brennan Kemmis, R.; Hardy, I.; Ponte, P. Relational architectures: Recovering solidarity and agency as living practices in education. Pedagog. Cult. Soc. 2010, 18, 43-54. [CrossRef]

40. Kemmis, S.; McTaggart, R.; Nixon, R. The Action Research Planner: Doing Critical Participatory Action Research; Springer: Singapore, 2013.

41. Martin, K.L. Ways of knowing, being and doing: A theoretical framework and methods for Indigenous and Indigenist re-search. JAS 2003, 27, 203-214. [CrossRef] 
42. Blue, L.E.; Pinto, L.E. Other ways of being: challenging dominant financial literacy discourses in Indigenous context. Aust. Educ. Res. 2017, 44, 55-70. [CrossRef]

43. Canadian Centre for Financial Literacy (CCFL). Programs and Services Training and Capacity Building. 2013. Available online: http:/ / www.theccfl.ca/Services/Training-Capacity-Building.aspx (accessed on 17 October 2013).

44. Lucey, T.A. A critically compassionate approach to financial literacy: A pursuit of moral spirit. Educ. Sci. 2018, 8, 152. [CrossRef]

45. Arthur, C. Financial literacy education for citizens: What kind of responsibility, equality and engagement? CSEE 2012, 11, 163-176. [CrossRef]

(C) 2019 by the author. Licensee MDPI, Basel, Switzerland. This article is an open access article distributed under the terms and conditions of the Creative Commons Attribution (CC BY) license (http:/ / creativecommons.org/licenses/by/4.0/). 